\title{
Cerrar fileiras, aprender com os que lutam: reflexões sobre direitos em xeque no Brasil hoje
}

\author{
DOI: 10.11606/issn.2316-9133.v25i25p29-30
}

O ano de 2016 custou a passar. Enquanto a nossa revista celebrava 25 anos de sua criação, o Brasil testemunhava um dos momentos mais dramáticos da história de sua jovem democracia. Em abril, assistíamos à votação do impeachment da primeira mulher a ocupar o mais alto cargo executivo do país, a presidenta Dilma Rousseff, na Câmara dos Deputados. Citações a torturadores dos tempos da ditadura, elogio ao Golpe de 1964, incontáveis menções à família e louvações a Deus como justificativas de voto tornavam evidente que o centro da peça jurídica, as chamadas "pedaladas fiscais", não estava entre os problemas mais graves da atual crise política. Dois dias depois, Michel Temer assumia a presidência interinamente, até que, em agosto, os senadores consumaram um processo de impeachment de questionável base jurídica e ele pôde, então, tornar-se o novo presidente da República.

Entre uma reunião e outra, nós, editores da Cadernos de Campo, comentávamos a velocidade impressionante com que o atual governo empreendia um verdadeiro desmonte de direitos sociais, como os ameaçados pelas propostas da PEC 241/55 (a conhecida "PEC do fim do mundo", que restringe os investimentos em saúde e educação por vinte anos), as revisões de demarcações de terras indígenas e o enfraquecimento ou extinção de pastas ministeriais dedicadas às questões ambientais e sociais (Desenvolvimento Agrário, das Mulheres, da Igualdade Racial e dos Direitos Humanos, por exemplo). Mais do que as agitações políticas, assustava-nos todo um rearranjo dos parâmetros de justiça social reconhecidos - ainda que fragilmente - a partir de décadas de lutas populares e avanços duramente conquistados.

"Precisamos nos posicionar diante da atual conjuntura", falávamos em nossas reuniões quinzenais. Mas como? De tudo, restava-nos uma só certeza: a de que a revista Cadernos de Campo, o primeiro periódico discente dos programas de pós-graduação em antropologia do Brasil, não poderia se esquivar de tratar dos temas que a faziam pulsar, acadêmica e politicamente. O diálogo com o mundo fora dos muros da Academia se faz tão necessário quanto urgente. Questões indígenas, de raça, de gênero e sexualidade, entre muitas outras, passam por um momento de retrocessos antidemocráticos alarmantes. Retrocessos que, em alguns casos, cabe lembrar, já se faziam sentir durante o governo do Partido dos Trabalhadores (PT). 
Convidamos, então, pesquisadores cujos interlocutores se situam em campos particularmente perpassados por essas investidas, e que resistem historicamente a todo um contexto de desigualdades e vulnerabilidades, para contribuir com reflexões em torno das suas especialidades temáticas. A professora Lilia Schwarcz e o mestrando Hélio Menezes, ambos do Programa de Pós-Graduação em Antropologia Social da Universidade de São Paulo, assinam em coautoria "Quando o passado atropela o presente: notas de um Brasil que insiste no racismo", sobre o descompasso desconcertante entre os tempos passado e presente e sua constante reinvenção de práticas políticas e retóricas discursivas racistas. Já as professoras Adriana Vianna e Maria Elvira Benítez, do Museu Nacional da Universidade Federal do Rio de Janeiro, trazem um panorama atual das políticas envolvendo gênero e sexualidade. As autoras de "Gênero e sexualidade: estamos no canto do ringue?" costuram a "metáfora do boxe" para comentar os "golpes e contra golpes" dos últimos meses e se perguntam: "em que ponto da batalha ou em que lugar do ringue se encontram as diferentes perspectivas sobre gênero e sexualidade no cenário político que vivemos?”.

Nessa perspectiva, Bruno Morais, mestre pelo Programa de Pós-Graduação em Antropologia Social da Universidade de São Paulo e assessor jurídico do Centro de Trabalho Indigenista e da Comissão Guarani Yvyrupa, chama a atenção para o "O golpe nosso de cada dia: as mui familiares ameaças aos direitos dos povos indígenas". O autor faz uma abordagem cronológica dos acontecimentos, a partir do governo Temer, e começa a reflexão pelo primeiro dia da nova presidência, quando lideranças indígenas procuraram Alexandre de Moraes, Ministro da Justiça, para comentar o desaparecimento da Funai na medida provisória que reorganizava a Esplanada dos Ministérios e o "boato" de que as demarcações do governo Dilma seriam anuladas. Por fim, a professora Ana Claudia Marques e as mestras Ana Letícia de Fiori, Cibele Barbalho Assênsio, Fabiana de Andrade, Jacqueline Moraes Teixeira, Letizia Patriarca e Talita Lazarin Dal' Bó, todas do PPGAS/USP e integrantes da Comissão Permanente de Ações Afirmativas do Programa, fazem uma ponte entre a conjuntura atual e a situação da ampliação de políticas afirmativas na educação superior, conectando a antropologia aos anseios de inclusão social e ao avanço da produção e circulação do conhecimento. 